\title{
Immobilized Lipase Based on Hollow Mesoporous Silicon Spheres for Efficient Enzymatic Synthesis of Resveratrol Ester Derivatives
}

Liu-Jia Xü, Tao Yang", Jing Wang, Feng-Hong Huang, Ming-Ming Zheng*

Oil Crops Research Institute, Chinese Academy of Agricultural Sciences, Hubei Key

Laboratory of Lipid Chemistry and Nutrition, Key Laboratory of Oilseeds Processing,

Ministry of Agriculture, Wuhan 430062, China

*Corresponding author: zhengmingming@,caas.cn

${ }^{\#}$ L.-J.X. and T.Y. contributed equally to this work. 


\section{Captions in Supporting Information}

Supplementary methods:

Measurement of the immobilized CSL activity and stability.

Measurement of the loading amount and immobilization efficiency of CSL@HMSS-

$\mathrm{C}_{8}$.

Supplementary Tables:

Table S1. Elemental content data (atomic \%) of HMSS and HMSS-C $\mathrm{C}_{8}$ and the grafting degree of $\mathrm{C}_{8}$.

Table S2. Comparison of lipase activity and specific activity between free CSL and CSL@HMSS- $\mathrm{C}_{8}$ and the lipase activity recovery of CSL@HMSS- $\mathrm{C}_{8}$.

Table 3. Comparison between reported enzymatic methods and that in this work for the synthesis of resveratrol ester with vinyl acetate.

Supplementary Figures:

Figure S1. Mass spectra of resveratrol acetyl esters. (a, resveratrol; b, 4'-O-acetylresveratrol; c, 3-O-acetyl-resveratrol; d, 3,5-di-O-acetyl-resveratrol).

Figure S2. The ${ }^{1} \mathrm{H}$ NMR spectrogram of resveratrol acetyl esters. (resveratrol, 4'-Oacetyl-resveratrol and 3-O-acetyl-resveratrol were dissolved in DMSO-d6, 3,5-di-Oacetyl-resveratrol was dissolved in $\mathrm{CDCl}_{3}$ )

Figure S3. HPLC chromatogram of resveratrol esters produced by free CSL and immobilized CSL. Reaction was carried out in MTBE $(5 \mathrm{~mL})$ containing resveratrol 
$(50 \mathrm{mM})$, vinyl acetate $(750 \mathrm{mM})$ and lipase $(0.1 \mathrm{~g})$ under shaking incubator $\left(35^{\circ} \mathrm{C}\right.$, 200rpm) for $30 \mathrm{~min}$ (free lipase for 1 hour). (a, resveratrol; b, 4'-O-acetyl-resveratrol; c, 3-O-acetyl-resveratrol; d, 3,5-di-O-acetyl-resveratrol). 
Measurement of the Immobilized CSL Activity and Stability. The immobilized

CSL activity was measured by the detection at $410 \mathrm{~nm}$ on a UV/VIS spectrophotometer of the p-nitrophenol (p-NP) resulting from the enzymatic hydrolysis of p-nitrophenyl palmitate (p-NPP) in PBS (50 mM, pH 7.0) under $37^{\circ} \mathrm{C}$ for $5 \mathrm{~min}$ in shaker (200 rpm). One unit (U) of lipase activity is defined as the amount of lipase which catalyzes the production of $1 \mu \mathrm{mol}$ of p-nitrophenol per minute under $37^{\circ} \mathrm{C}$.

The specific activity is defined by the following equation:

$$
\text { Specific activity }(\mathrm{U} / \mathrm{g} \text { protein })=\frac{\text { total activity of lipase }}{\text { protein content of lipase }}
$$

The lipase activity recovery after immobilization is defined by the following equation:

$$
\text { Lipase activity recovery }(\%)=(B \times 100) / A
$$

where $\mathrm{A}$ is the total activity of CSL added to the initial immobilization solution and $\mathrm{B}$ is the activity of immobilized CSL.

The thermal stability assays were performed by the incubation for different times ( 0 $120 \mathrm{~min}$ ) of free CSL and CSL@HMSS-C $\mathrm{C}_{8}$ at $60^{\circ} \mathrm{C}$ and $80^{\circ} \mathrm{C}$, respectively. Residual activities were measured with the p-NPP method under the conditions as described above. Relative activity is calculated as the ratio of the activity of lipase measured incubation to the maximal activity of the lipase.

\section{Measurement of the Loading Amount and Immobilization Efficiency of}

CSL@HMSS-C 8 . The loading amount of immobilized lipase and immobilization efficiency were determined by using the equation:

$$
\begin{gathered}
\text { Loading amount }(\mathrm{mg} / \mathrm{g})=\left[\left(C_{0}-C\right) V\right] / M \\
\text { Immobilization efficiency }(\%)=\frac{\mathrm{C}_{0}-\mathrm{C}}{\mathrm{C}_{0}}
\end{gathered}
$$


where $\mathrm{C}_{0}$ and $\mathrm{C}$ are the concentrations of protein in the initial and final solutions before and after immobilization, respectively $(\mathrm{mg} / \mathrm{mL})$; $\mathrm{V}$ is the volume of the aqueous solution $(\mathrm{mL})$; and $\mathrm{M}$ is the mass of $\mathrm{HMSS}-\mathrm{C}_{8}(\mathrm{~g})$. The amounts of protein were determined according to the bicinchoninic acid (BCA) method. 
Table S1. Elemental content data (atomic \%) of HMSS and $\mathrm{HMSS}-\mathrm{C}_{8}$ and the grafting degree of $\mathrm{C}_{8}$.

\begin{tabular}{ccccc}
\hline particle & $\mathrm{C}(\%)$ & $\mathrm{H}(\%)$ & $\mathrm{O}(\%)$ & Grafting degree (mmol/g) \\
\hline HMSS & 0.32 & 0.88 & 12.16 & - \\
HMSS-C 8 & 17.04 & 2.97 & 2.46 & 1.77 \\
\hline
\end{tabular}

Table S2. Comparison of lipase activity and specific activity between free CSL and CSL@HMSS-C $\mathrm{H}_{8}$ and the lipase activity recovery of CSL@HMSS-C 8.

\begin{tabular}{cccc}
\hline & Lipase activity & Specific activity & Lipase activity \\
& $(\mathrm{U} / \mathrm{g})$ & $(\mathrm{U} / \mathrm{g}$ protein $)$ & recovery $(\%)$ \\
\hline Free CSL & 0.845 & 21 & - \\
$\mathrm{CSL} @ \mathrm{HMSS}-\mathrm{C}_{8}$ & 6.071 & 46 & $88 \%$ \\
\hline
\end{tabular}


Table S3. Comparison between reported enzymatic methods and that in this work for the synthesis of resveratrol ester with vinyl acetate.

\begin{tabular}{|c|c|c|c|c|c|}
\hline Enzyme & Solvent & Time & Regioselectivity & $\begin{array}{c}\text { Conversion } \\
\text { (\%) }\end{array}$ & Ref. \\
\hline Lipase CSL & $\begin{array}{l}\text { tert-butyl } \\
\text { methyl ether }\end{array}$ & $4 \mathrm{~h}$ & 4'-OH & 75 & (1) \\
\hline Novozym 435 & $\begin{array}{c}\text { 2-methyl-2- } \\
\text { butanol }\end{array}$ & $11 \mathrm{~h}$ & 4'-OH & 95.2 & (2) \\
\hline Novozym 435 & $\begin{array}{c}2- \\
\text { methylbutan- } \\
\text { 2-ol }\end{array}$ & 3 days & 4'-OH & 50 & (3) \\
\hline Lipase QLG & $\begin{array}{c}\text { 2-methyl-2- } \\
\text { butanol }\end{array}$ & $12 \mathrm{~h}$ & $3-\mathrm{OH}$ & 75 & \\
\hline Lipase QLG & $\begin{array}{c}\text { 2-methyl-2- } \\
\text { butanol }\end{array}$ & $160 \mathrm{~h}$ & $3-\mathrm{OH}>4{ }^{\prime}-\mathrm{OH}$ & 60 & (4) \\
\hline Novozym 435 & $\begin{array}{c}\text { 2-methyl-2- } \\
\text { butanol }\end{array}$ & $50 \mathrm{~h}$ & 4'-OH & 80 & \\
\hline $\begin{array}{l}\text { C. antarctica } \\
\text { lipase }\end{array}$ & $\begin{array}{l}\text { t-amyl } \\
\text { alcohol }\end{array}$ & $90 \mathrm{~h}$ & 4'-OH & 40 & (5) \\
\hline $\begin{array}{c}\text { CSL@HMSS- } \\
\mathrm{C}_{8}\end{array}$ & $\begin{array}{c}\text { tert-butyl } \\
\text { methyl ether }\end{array}$ & $2 \mathrm{~h}$ & $3-\mathrm{OH}>4^{\prime}-\mathrm{OH}$ & 98.8 & $\begin{array}{l}\text { This } \\
\text { work }\end{array}$ \\
\hline
\end{tabular}



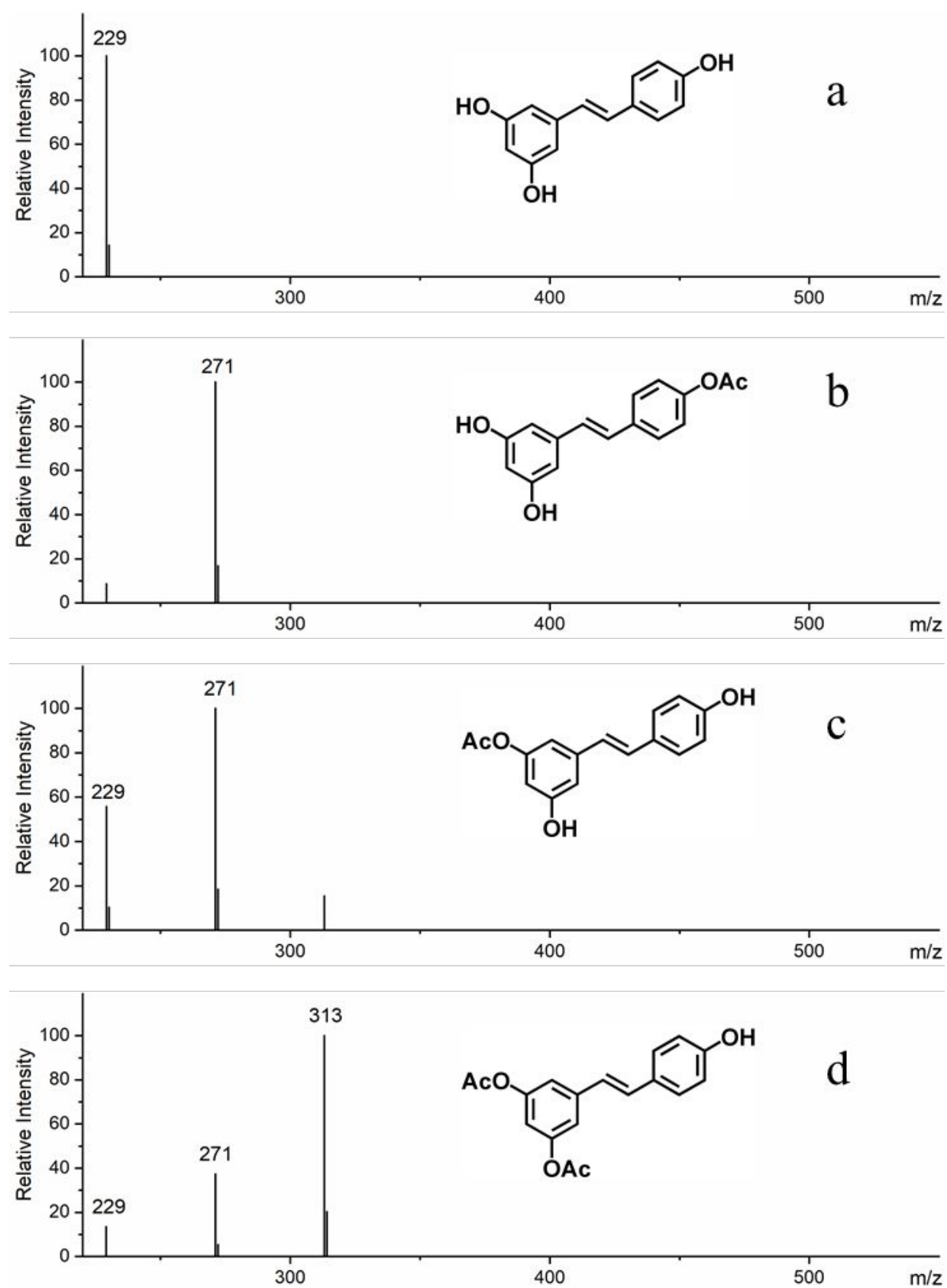

Figure S1. Mass spectra of resveratrol acetyl esters. (a, resveratrol; b, 4'-O-acetylresveratrol; c, 3-O-acetyl-resveratrol; d, 3,5-di-O-acetyl-resveratrol). 

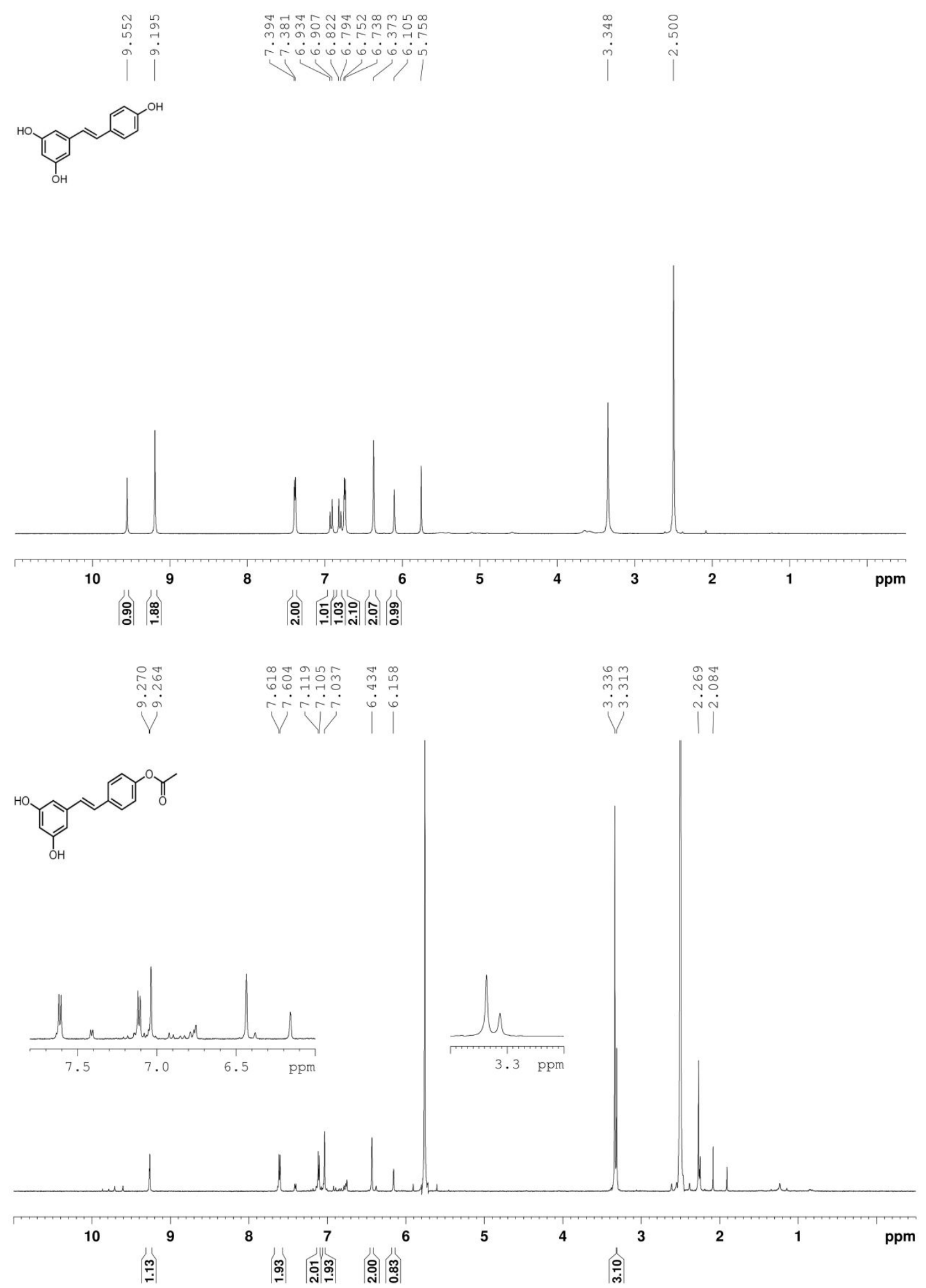

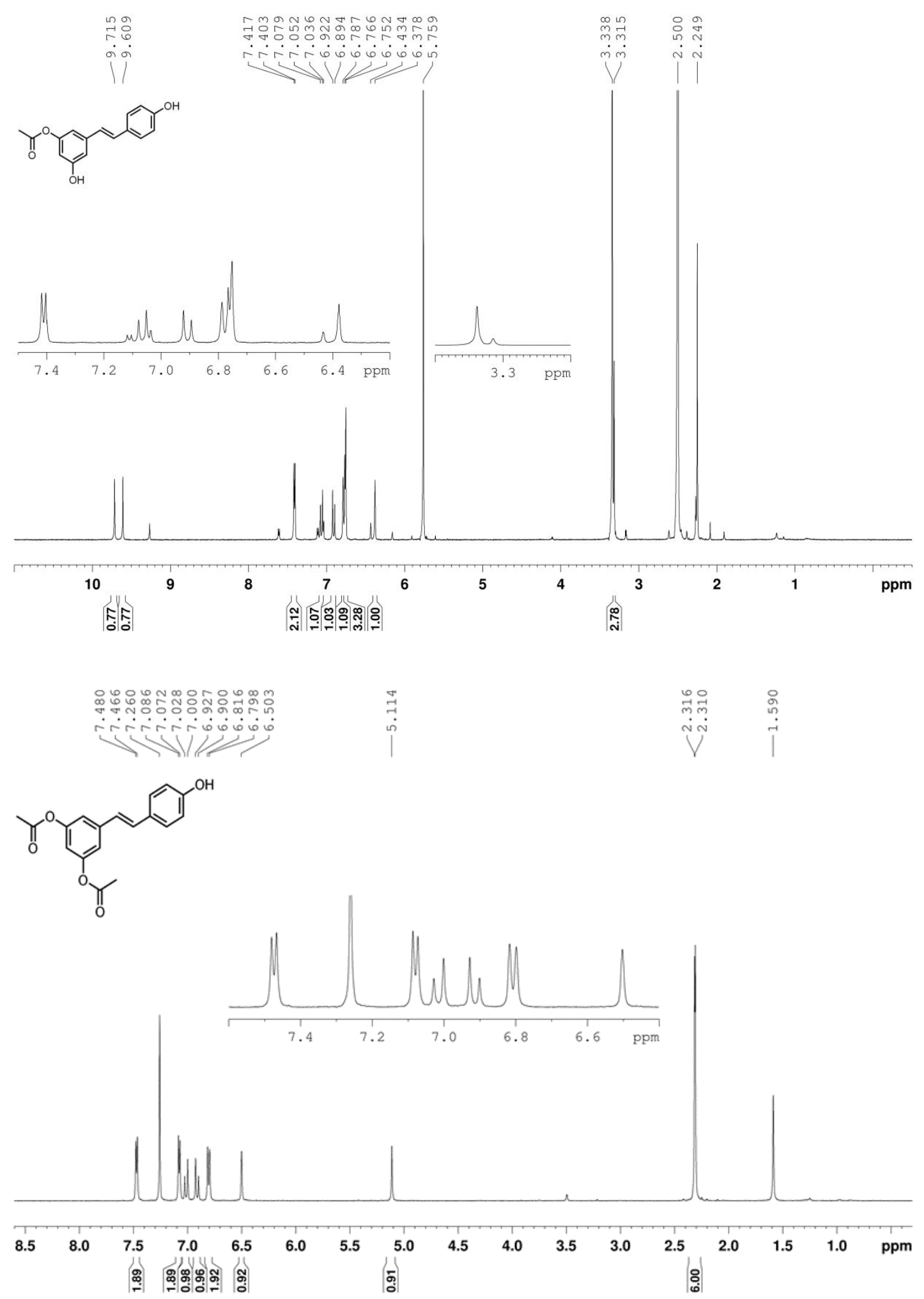

Figure S2. The ${ }^{1} \mathrm{H}$ NMR spectrogram of resveratrol acetyl esters. (resveratrol, 4'-Oacetyl-resveratrol and 3-O-acetyl-resveratrol were dissolved in DMSO-d6, 3,5-di-Oacetyl-resveratrol was dissolved in $\mathrm{CDCl}_{3}$ ) 


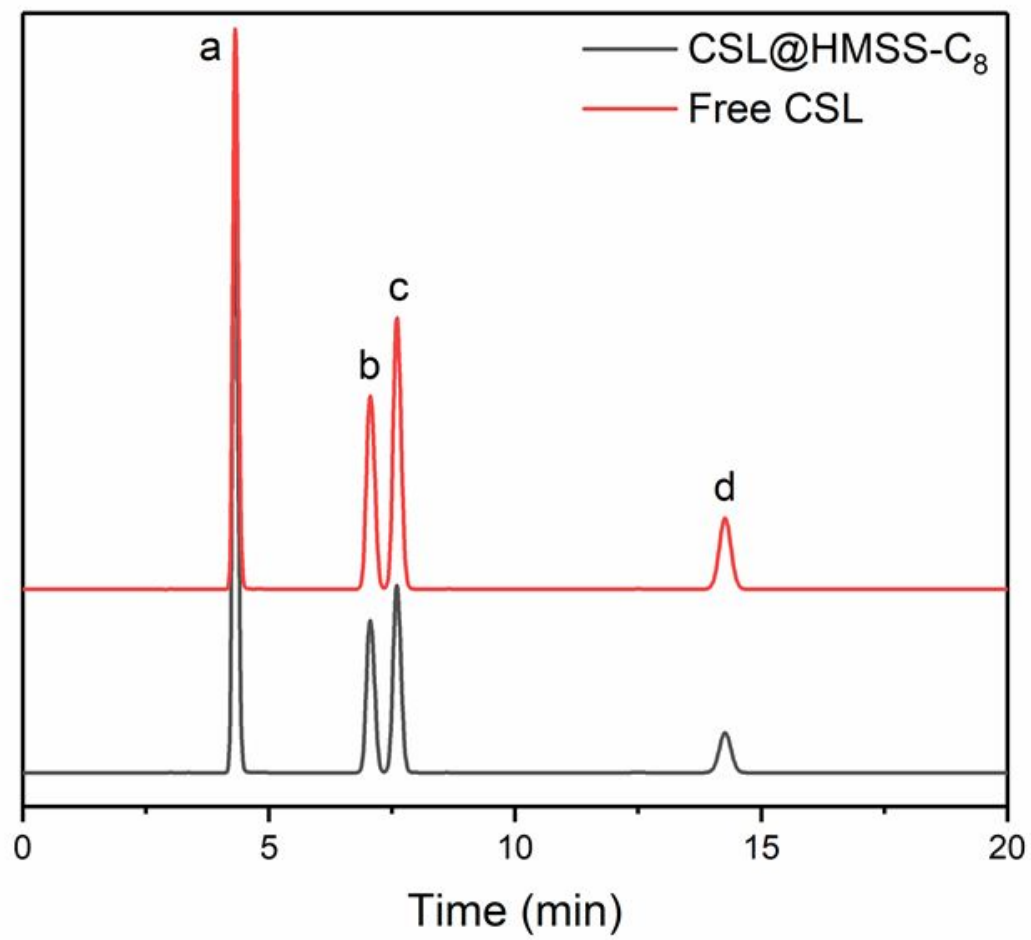

Figure S3. HPLC chromatogram of resveratrol esters produced by vinyl acetate as acyl donor. Reaction was carried out in MTBE (5 mL) containing resveratrol (50 $\mathrm{mM})$, vinyl acetate $(750 \mathrm{mM})$ and lipase $(0.1 \mathrm{~g})$ under shaking incubator $\left(35^{\circ} \mathrm{C}\right.$, 200rpm) for $30 \mathrm{~min}$ (free lipase for 1 hour). (a, resveratrol; b, 4'-O-acetyl-resveratrol; c, 3-O-acetyl-resveratrol; d, 3,5-di-O-acetyl-resveratrol). 


\section{REFERENCES}

(1) Wang, Z.; Zhang, Y.; Zheng, L.; Cui, X.; Huang, H.; Geng, X.; Xie, X. Regioselective acylation of resveratrol catalyzed by lipase under microwave. Green Chem. Lett. Rev. 2018, 3, 312-317.

(2) Kuo, C. H.; Hsiao, F. W.; Chen, J. H.; Hsieh, C. W.; Liu, Y. C.; Shieh, C.-J. Kinetic aspects of ultrasound-accelerated lipase catalyzed acetylation and optimal synthesis of 4'-acetoxyresveratrol. Ultrason. Sonochem. 2013, 1, 546-552.

(3) Teng, R. W.; Bui, T. K. A.; Mcmanus D. Regioselective acylation of several polyhydroxylated natural compounds by Candida antarctica lipase B. Biocatalysis, 2005, 2,109-116.

(4) Torres, P.; Poveda, A.; Jimenez-Barbero, J. S.; Ballesteros, A.; Plou, F. J. Regioselective lipase-catalyzed synthesis of 3-O-acyl-derivatives of resveratrol and study of their antioxidant properties. J Agric Food Chem. 2010, 58, 807-813.

(5) Nicolosi, G.; Spatafora, C.; Tringali, C. Chemo-enzymatic preparation of resveratrol derivatives. J. Mol. Catal. B: Enzym. 2002, 5, 223-229. 